\title{
Silver Ecotoxicity Estimation by the Soil State Biological Indicators
}

\author{
S. I. Kolesnikov $(\mathbb{D}$, N. I. Tsepina, L.V. Sudina, T. V. Minnikova, K. Sh. Kazeev, \\ and Yu. V. Akimenko \\ Department of Ecology and Nature Management, Southern Federal University, 194/1 pr. Stachki, Rostov-on-Don 344090, Russia \\ Correspondence should be addressed to S. I. Kolesnikov; kolesnikov@sfedu.ru
}

Received 13 March 2020; Revised 13 May 2020; Accepted 20 May 2020; Published 9 June 2020

Academic Editor: Amaresh K. Nayak

Copyright (c) 2020 S. I. Kolesnikov et al. This is an open access article distributed under the Creative Commons Attribution License, which permits unrestricted use, distribution, and reproduction in any medium, provided the original work is properly cited.

\begin{abstract}
The use of silver in various spheres of life and production leads to an increase in environmental pollution, including soil. At the same time, the environmental consequences of silver pollution of soils have been studied to a much lesser extent than those of other heavy metals. The aim of this study is to estimate silver ecotoxicity using the soil state biological indicators. We studied soils that are significantly different in resistance to heavy metal pollution: ordinary chernozem (Haplic Chernozems, Loamic), sierosands (Haplic Arenosols, Eutric), and brown forest acidic soil (Haplic Cambisols, Eutric). Contamination was simulated in the laboratory. Silver was introduced into the soil in the form of nitrate in doses of 1,10 , and $100 \mathrm{mg} / \mathrm{kg}$. Changes in biological parameters were assessed 10,30, and 90 days after contamination. Silver pollution of soils in most cases leads to deterioration of their biological properties: the total number of bacteria, the abundance of bacteria of the genus Azotobacter, the activity of enzymes (catalase and dehydrogenases), and the phytotoxicity indicators decrease. The degree of reduction in biological properties depends on the silver concentration in the soil and the period from the contamination moment. In most cases, there is a direct relationship between the silver concentration and the degree of deterioration of the studied soil properties. The silver toxic effect was most pronounced on the 30th day after contamination. In terms of their resistance to silver pollution, the studied soils are in the following order: ordinary chernozem $>$ sierosands $\geq$ brown forest soil. The light granulometric composition of sierosands and the acidic reaction of the environment of brown forest soils, as well as the low content of organic matter, contribute to high mobility and, consequently, high ecotoxicity of silver in these soils. The regional maximum permissible concentration (rMPC) of silver in ordinary chernozem (Haplic Chernozems, Loamic) is $4.4 \mathrm{mg} / \mathrm{kg}$, in sierosands (Haplic Arenosols, Eutric) $0.9 \mathrm{mg} / \mathrm{kg}$, and in brown forest soils (Haplic Cambisols, Eutric) $0.8 \mathrm{mg} / \mathrm{kg}$.
\end{abstract}

\section{Introduction}

The silver technophility over the past 50 years has been growing at an exponential rate and, according to forecasts, will only increase soon [1]. The main anthropogenic sources of silver pollution of the environment, including soils, are emissions from thermal power plants during coal combustion [2-6], nonferrous and ferrous metallurgy enterprises [7], cement plants [8], solid waste landfills [9], production of photo and electrical materials [10], pesticides [11], the use of sewage sludge as fertilizers [12], etc. The extent and degree of silver pollution in soils are increasing every year $[13,14]$.
In modern conditions of nanotechnology development, silver nanoparticles are increasing sources of environmental pollution [15-18].

Silver toxicity has been established for bacteria [19-23], plants [16, 24-26], nematodes [27], earthworms [28], mollusks [29], fish [30,31], rats [32, 33], mice [34], and human $[35,36]$. Silver ions $\mathrm{Ag}^{+}$possess genotoxic properties $[37,38]$.

Silver is capable of interacting with various proteins [39-41], and, therefore, the mechanism of silver toxicity is apparently the same as that of other heavy metals and metalloids-inhibition of enzymes and a decrease in the permeability of biological membranes [12, 32, 33], DNA 
damage [30, 42], metabolic disturbance [29, 42], and cell necrosis [33].

At the same time, the environmental effects of silver soil pollution have been studied to a much lesser extent than those of other heavy metals such as lead, cadmium, and mercury. Therefore, it seems relevant to identify patterns of the effect of silver on the state of soils depending on the dose of metal and the period from the moment of contamination, to establish limits on the resistance of different soils to pollution, and to normalize the silver content in soils.

The aim of this work is to assess the ecotoxicity of silver by biological indicators of soil condition, which differ significantly in the degree of resistance to pollution.

\section{Materials and Methods}

Soils of the south of Russia, significantly differing in properties determining the resistance to heavy metal pollution, were used as objects of study: ordinary chernozem (Botanical Garden of SFU, the Rostov-on-Don city, $47^{\circ} 14^{\prime} 17.54^{\prime \prime}$ north latitude, $39^{\circ} 38^{\prime} 33.22^{\prime \prime}$ east longitude), sierosands (the Rostov Region, the Ust-Donetsk Region, Verkhnekundryuchenskaya station, $47^{\circ} 46.015^{\prime}$ north latitude, $40^{\circ} 51.700^{\prime}$ east longitude), and brown forest acidic soil (the Republic of Adygea, the Maykopsky district, Nikel settlement, $44^{\circ} 10.649^{\prime}$ north latitude, $40^{\circ} 9.469^{\prime}$ east longitude).

Ordinary chernozem (according to IUSS Working Group WRB [43]-Haplic Chernozems, Loamic) is characterized by a heavy loam granulometric composition, an average organic matter content of $3.7 \%$, and a neutral reaction of the medium $\mathrm{pH}=7.8$. Sierosands (Haplic Arenosols, Eutric) are characterized by light particle size distribution; low organic matter content, 2.3\%; and neutral $\mathrm{pH}$, 6.8. Brown forest soils (Haplic Cambisols, Eutric) are characterized by heavy loam granulometric composition; low humus content, $1.8 \%$; and acid reaction of the medium, 5.8 .

Silver soil contamination was modeled in the laboratory. The soil was taken from the top layer $0-10 \mathrm{~cm}$ because silver usually accumulates in the surface layers of the soil [44].

According to different authors, the silver content in unpolluted soil is $0.01-1 \mathrm{mg} / \mathrm{kg}[45,46]$, from 0.07 to $0.1 \mathrm{mg}$ / $\mathrm{kg}$ [44]. According to various sources, the content of silver in contaminated soils is up to $8 \mathrm{mg} / \mathrm{kg}$ [47], $9 \mathrm{mg} / \mathrm{kg}$ [45], $19.5 \mathrm{mg} / \mathrm{kg}$ [48], $23 \mathrm{mg} / \mathrm{kg}$ [49], and $35.9 \mathrm{mg} / \mathrm{kg}$ [50], and it is up to $7000 \mathrm{mg} / \mathrm{kg}$ in the soils of ore deposits [51].

Since the maximum permissible concentration (MPC) of silver in the soil has not been developed, its content in the soil was expressed in the conditionally permissible concentration (CPC). CPC values were taken equal to three background silver concentrations in the soil. This is because the MPCs of most heavy metals and metalloids are about three to four background concentrations in the soil [52]. The background silver content in ordinary chernozem is $0.303 \mathrm{mg} / \mathrm{kg}$, brown forest soil $0.282 \mathrm{mg} / \mathrm{kg}$, and sulphurous sand $0.215 \mathrm{mg} / \mathrm{kg}$ (silver content in soils was determined by inductively coupled plasma mass spectrometry). Accordingly, CPC was taken equal to $1 \mathrm{mg} / \mathrm{kg}$. Silver was introduced into the soil in the amount of 3.30 and 300 background concentrations (1.10 and $100 \mathrm{mg} / \mathrm{kg}$, respectively). Since the silver content in contaminated soils often reaches $35 \mathrm{mg} / \mathrm{kg}$ [50] and in the soils of ore deposits up to $7000 \mathrm{mg} / \mathrm{kg}$ [51], the studied concentrations and even high silver concentrations in the soil are already found. In addition, one of the objectives of the study is to forecast the possible negative consequences of this level of pollution.

Silver was introduced into the soil in the form of nitrate $\left(\mathrm{AgNO}_{3}\right)$. When contaminated, silver enters the soil in the form of sulfates and sulfides [53] and more recently in the form of nanoparticles $[17,18]$. Many authors consider silver nitrate to be the most toxic compound [24, 54, 55]. Silver nitrate is a highly soluble substance in water. This allows you to evaluate the maximum toxicity of silver, as well as to achieve a uniform distribution of silver in the soil.

Each soil sample (weighing $1 \mathrm{~kg}$ ) was incubated in plastic vessels in triplicate at room temperature $\left(20-22^{\circ} \mathrm{C}\right)$ and optimal moisture (60\% of field moisture capacity).

The biological properties of the soil were investigated first since they were the first to respond to external influences. They are significantly more sensitive and informative compared to other soil properties [56].

In the first model experiment, the change in the biological parameters of different soils of the south of Russia (ordinary chernozem, brown forest soil, and sulphurous sand) was assessed during short-term exposure (10 days) of the pollutant. In the second model experiment, the change in the biological parameters of ordinary chernozem was evaluated 10, 30, and 90 days after contamination. The objective of the first experiment was to compare the stability of three different soils, which differ significantly in resistance to chemical pollution. The objective of the second experiment was to investigate the dynamics of changes in the state of soil over time.

After this period, the entire mass of soil was removed from the vegetation vessel and mixed, thereby obtaining a "medium sample" from which samples were taken to determine biological indicators-3 samples from each vessel.

Laboratory and analytical studies were performed using generally accepted methods. Silver toxicity was assessed using biological analysis methods. The total number of bacteria, the abundance of bacteria of the genus Azotobacter, the activity of catalase and dehydrogenases, and the phytotoxic properties of the soil (root length) were determined. The total number of bacteria in the soil was determined by luminescence microscopy $(n=720: 3$ vegetation vessels with soil $\times 3$ soil samples $\times 4$ square centimeters on glass slides $\times 20$ visual fields); the abundance of bacteria of the genus Azotobacter was determined by the method of fouling lumps on Ashby medium ( $n=225: 3$ vegetation vessels with soil $\times 3$ soil samples in Petri dishes $\times 25$ lumps of fouling); catalase activity was determined according to the rate of decomposition of hydrogen peroxide $(n=36: 3$ vegetation vessels with soil in 3 biological replicates $\times 4$ analytical replicates); actively dehydrogenaseswas determined according to the rate of conversion of triphenyl tetrazolium chloride to triphenyl formazan ( $n=36: 3$ vegetation vessels with soil in 3 biological replicates $\times 4$ analytical replicates); 
TABLE 1: Change in environmental indicators of soils in the south of Russia with silver pollution over 10 days of the experiment.

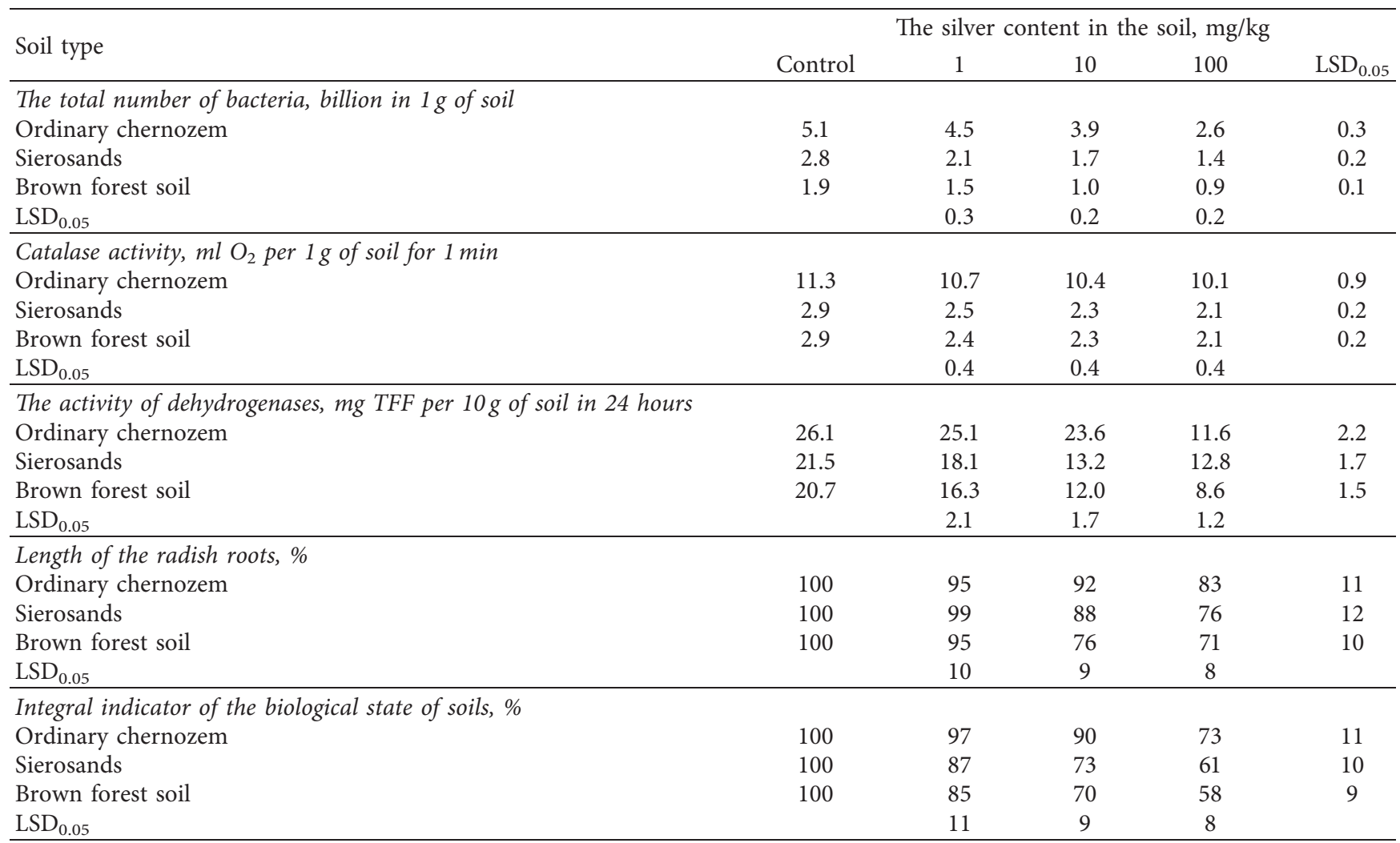

and soil phytotoxicity was judged by the germination of radish seeds (Raphanus sativus L.) variety (16 days) and root length ( $n=225: 3$ vegetation vessels in 3 biological replicates in Petri dishes $\times 25$ radish seeds).

The choice of biological indicators is due to the following reasons. The total number of bacteria in the soil characterizes the state of reducers in the ecosystem. Bacteria of the genus Azotobacter are traditionally used as an indicator of chemical pollution of the soil. The activity of catalase and dehydrogenases reflects the intensity of mineralization processes in the soil. Oxidoreductases are the most sensitive to chemical pollution among enzymes [56]. Enzyme activity is an indicator of the potential biological activity of the soil. The length of radish roots was characterized by a more sensitive indicator than the length of shoots for the presence of toxicants in the soil [57]. The presented set of indicators gives an informative picture of the biological processes taking place in the soil and its ecological state.

Based on the above biological indicators, the integral indicator of the biological state (IIBS) of the soil was determined [56]. For the calculation of IIBS, the value of each of the above indicators on the control (in unpolluted soil) was taken as $100 \%$ and, relative to it, the values of other experimental variants (in polluted soil) were expressed as a percentage. Then, the average value of five selected indicators for each experiment was determined. The obtained value (IIBS) is expressed as a percentage concerning the control (to $100 \%$ ). The methodology used allows the integration of the relative values of different indicators, the absolute values of which cannot be integrated since they have different units of measurement.

To verify the obtained data for reliability, analysis of variance was carried out with the subsequent determination of the smallest significant difference (LSD).

\section{Results and Discussion}

It was found that silver pollution in most cases leads to deterioration in the biological properties of soils in the south of Russia (Table 1, Figure 1). The degree of reduction in biological properties depends on the silver concentration in the soil and the period from the contamination moment. In most cases, there is a direct relationship between the silver concentration and the degree of deterioration of the studied soil properties.

The total number of bacteria, the abundance of bacteria of the genus Azotobacter, the activity of catalase and dehydrogenase, and the length of radish roots are reduced.

Only in one variant of the experiment with a dose of 1 CPC of silver on the 30th day after contamination and only on ordinary chernozem, there was a statistically unreliable stimulating effect of silver on the activity of dehydrogenases recorded. Moreover, there are cases when small doses of silver stimulated the activity of urease and phosphatase [58]; the length of the roots of radishes, wheat, beans, and corn $[59,60]$; and nitrification process [61]. However, in the present study, stimulation only on the dehydrogenase activity was recorded. 


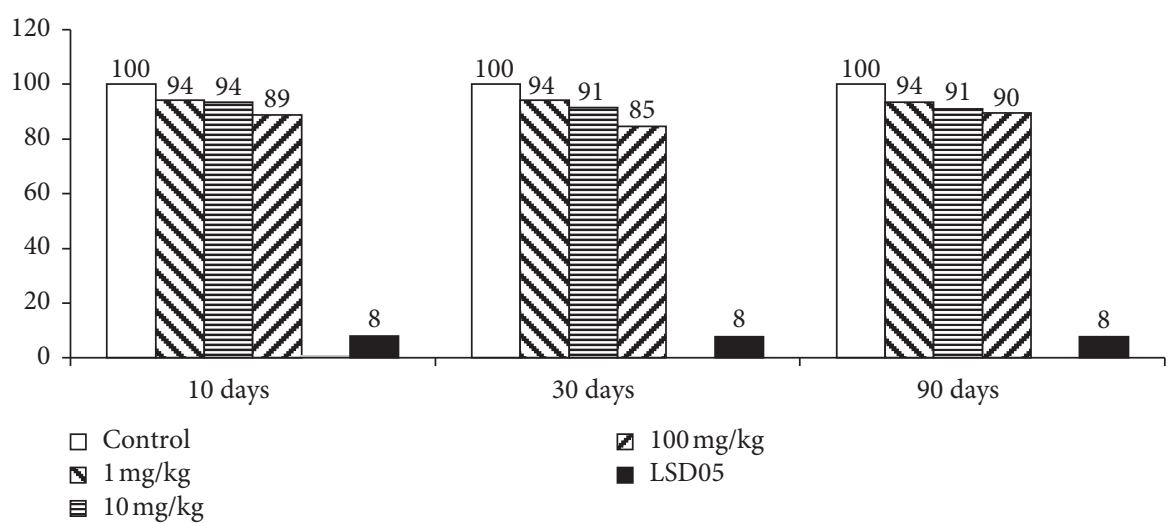

(a)

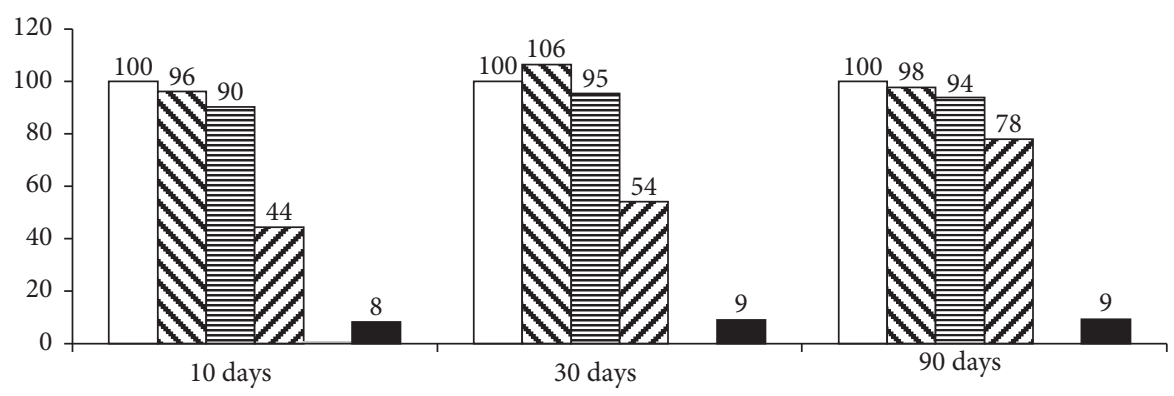

$\square$ Control
ه $1 \mathrm{mg} / \mathrm{kg}$
目 $10 \mathrm{mg} / \mathrm{kg}$

\ $100 \mathrm{mg} / \mathrm{kg}$

- LSD05

(b)

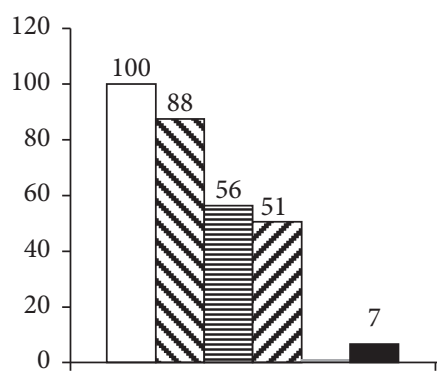

10 days

$\square$ Control

ه $1 \mathrm{mg} / \mathrm{kg}$

目 $10 \mathrm{mg} / \mathrm{kg}$

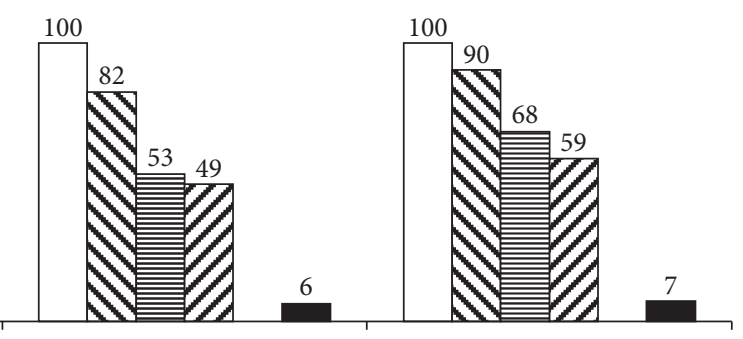

30 days

\ $100 \mathrm{mg} / \mathrm{kg}$

- LSD05

(c)

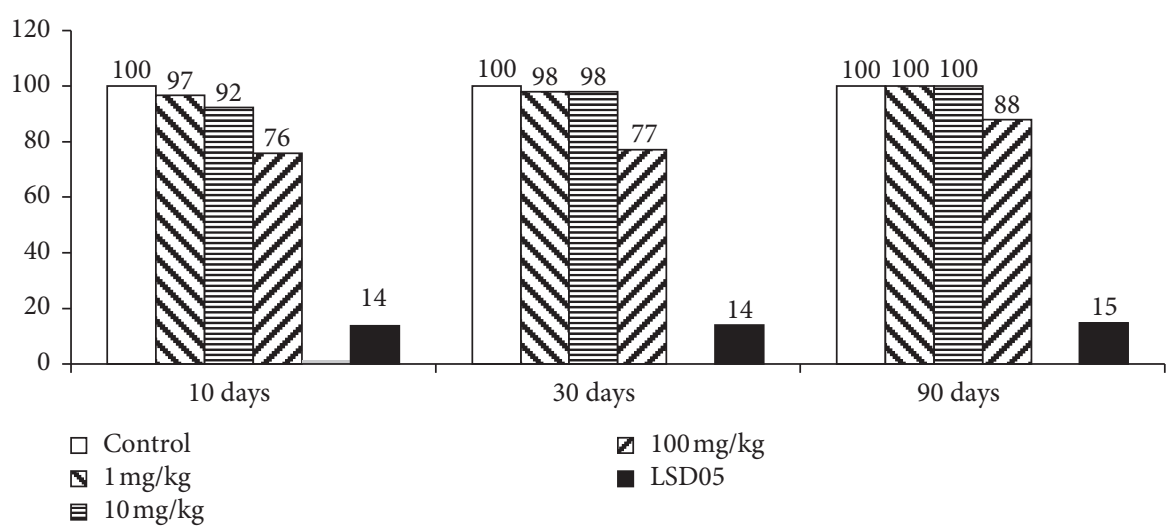

(d)

Figure 1: Continued. 


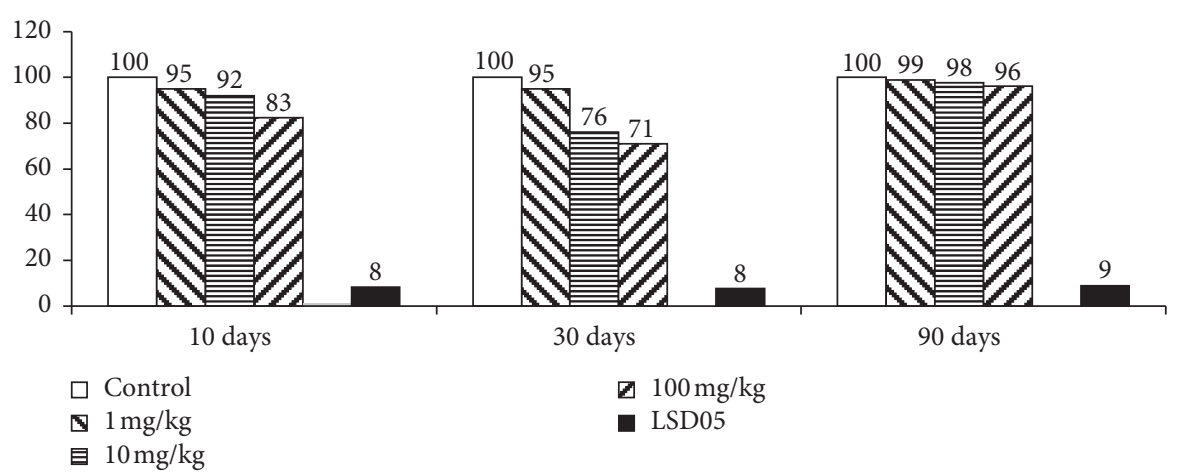

(e)

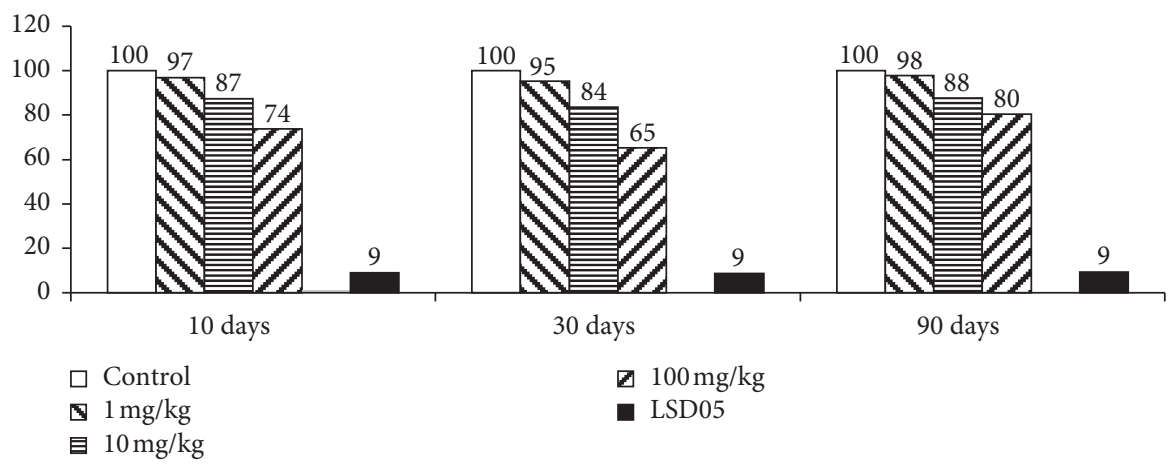

(f)

Figure 1: Changes in the biological state of chernozem 10, 30, and 90 days after silver contamination. (a) Catalase activity, (b) activity of dehydrogenases, (c) total number of bacteria, (d) the abundance of bacteria of the genus Azotobacter, (e) length of the radish roots, \%, and (f) integral indicator of the biological state of soils (IIBS).

When comparing the resistance of the three types of soils to silver pollution, the following order was obtained: ordinary chernozem $>$ sierosands $\geq$ brown forest soil. Light granulometric composition of sierosands and the acidic reaction of brown forest soils $(\mathrm{pH}=5.8)$, as well as low content of organic matter ( $1.8 \%$ and $2.3 \%$, respectively), contribute to high mobility and, consequently, high ecotoxicity of silver in these soils.

When assessing the dynamics of the biological state of the ordinary chernozem, it was noted that, for most biological indicators, the strongest decrease was recorded on the 30th day after pollution. On the 90th day, there was a tendency to restore the biological properties of ordinary chernozem, but the control values (before soil contamination) were not achieved. Similar regularities in the dynamics of biological properties of soils after pollution were obtained earlier for other heavy metals: $\mathrm{Hg}, \mathrm{Cd}, \mathrm{Pb}, \mathrm{Cr}, \mathrm{Cu}, \mathrm{Zn}$, etc. [62-64].

The biological indicators of soil contamination with silver were evaluated for their information content and sensitivity to determine the effectiveness of their use in monitoring, diagnosis, and regulation of soil contamination with silver.

The sensitivity of the indicator was assessed by the degree of decrease in its values in the variants with pollution compared to the control (Table 2).

With regard to the degree of sensitivity to soil pollution with silver, the biological indicators of ordinary chernozem can be ordered as follows: the total number of bacteria (66) $>$ dehydrogenase activity (84) $>$ radish root length (89) > catalase activity $(91)>$, abundance of bacteria of the genus Azotobacter (92)

The information content of the indicator was evaluated based on the tightness of the correlation between the indicator and the silver content in the soil (Table 3).

With respect to the degree of informative value, the biological indicators of ordinary chernozem form the following sequence:

dehydrogenase activity $(-0.99) \geq$ abundance of bacteria genus Azotobacter $(-0.99)>$ radish root length $(-0.86)$ $>$ catalase activity $(-0.76)>$, the total number of bacteria $(-0.72)$

Previous studies [66] have shown that soil pollution disrupts its ecosystem (biogeocenotic) functions. Violation of the ecosystem functions of the soil depends on the concentration of a pollutant in the soil. Violation of the ecosystem functions of the soil has the following sequence. First, there is a breakdown of information functions; then biochemical, physicochemical, chemical, and integral functions; and then physical functions. In environmental regulation of soil pollution, depending on the dose of pollutant in the soil, it is advisable to use the established pattern of disruption of ecosystem functions of the soil. Soil IIBS is used as an indicator of disturbance in the ecosystem functions of the soil. With a decrease in IIBS by less than $5 \%$, 
TABLE 2: Assessment of biological indicators of soil condition during silver contamination in terms of sensitivity and informative value.

\begin{tabular}{lcc}
\hline Indicator & Sensitivity $^{1}$ & Informative value $^{2}$ \\
\hline Number of bacteria & 66 & -0.72 \\
The abundance of bacteria of the genus Azotobacter & 92 & -0.99 \\
Catalase activity & 91 & -0.76 \\
Activity of dehydrogenases & 84 & -0.99 \\
Length of the radish roots & 89 & -0.86 \\
IIBS & 85 & -0.91 \\
\hline
\end{tabular}

${ }^{1}$ The sensitivity of the indicator is the degree of decrease in the biological indicator when the soil is contaminated with silver, $\%$ of the control (values are averaged over the doses and terms of pollution). ${ }^{2}$ The indicator informative value is the correlation coefficient ( $r$ ) between the content of silver in the soil and the biological indicator $(=0.05)$.

TABLE 3: The scheme of environmental regulation of silver pollution of soils of Southern Russia by the degree of violation of ecosystem (biogeocenotic) functions.

\begin{tabular}{|c|c|c|c|c|}
\hline Soils & $\begin{array}{c}\text { Not } \\
\text { polluted }\end{array}$ & Slightly polluted & Medium polluted & Highly polluted \\
\hline $\begin{array}{l}\text { Degree of soil } \\
\text { IIBS reduction }^{1}\end{array}$ & $<5 \%$ & $5-10 \%$ & $10-25 \%$ & $>25 \%$ \\
\hline $\begin{array}{l}\text { Violated } \\
\text { ecosystem } \\
\text { functions }\end{array}$ & - & Information & $\begin{array}{l}\text { Chemical, physicochemical, biochemical; } \\
\text { holistic }\end{array}$ & Physics \\
\hline Soils & & & The silver content in the soil, $\mathrm{mg} / \mathrm{kg}$ & \\
\hline $\begin{array}{l}\text { Ordinary } \\
\text { chernozem }\end{array}$ & $<0.5$ & $1.5-4.4$ & $4.4-106$ & $>106$ \\
\hline Sierosands & $<0.3$ & $0.5-0.9$ & $0.9-8$ & $>8$ \\
\hline Brown forest soil & $<0.3$ & $0.4-0.8$ & $0.8-6$ & $>6$ \\
\hline $\begin{array}{l}\text { Soil remediation } \\
\text { methods }\end{array}$ & $\begin{array}{l}\text { Not } \\
\text { required }\end{array}$ & $\begin{array}{l}\text { Phytoremediation, } \\
\text { flushing }\end{array}$ & $\begin{array}{l}\text { Chemical reclamation: the application of } \\
\text { organic substances, ion exchange resins, } \\
\text { phosphate fertilizers, lime, zeolites, etc. }\end{array}$ & $\begin{array}{l}\text { Removing contaminated soil and } \\
\text { replacing it with a new } \\
\text { environmentally and agriculturally } \\
\text { sound soil }\end{array}$ \\
\hline
\end{tabular}

${ }^{1}$ Determination of IIBS of soils according to Kolesnikov et al. [52]. ${ }^{2}$ Classification of ecosystem functions of soil by Dobrovolsky and Nikitin [65].

a disturbance in the ecosystem functions of the soil does not occur, but a decrease in the value of IIBS by $5-10 \%$ reveals a violation of information functions; by $10-25 \%$ biochemical, physicochemical, chemical, and integral functions; and more than $25 \%$ physical functions [52].

An important task of environmental regulation should be monitoring the basic ecosystem functions of the soil and preventing their violation. Thus, a decrease in IIBS by more than $10 \%$ indicates serious disturbances in the functioning of the soil. The dose of a soil polluting substance, causing a $10 \%$ decrease in soil IIBS, can be considered the rMPC of this substance in this soil, the excess of which is unacceptable.

To calculate the concentration of a pollutant, which causes a different degree of reduction in the soil IIBS, one can apply regression equations, which describes the dependence of the decrease in the values of IIBS on the content of a pollutant in the soil. Using the regression equation, you can calculate the concentration of pollutant that causes a violation of certain groups of ecosystem functions of the soil.

As can be seen from Table 2, if, for example, in ordinary chernozem, the silver content does not exceed $0.5 \mathrm{mg} / \mathrm{kg}$, then the ecological functions of the soil are not disrupted. However, if the silver concentration is between 1.5 and $4.4 \mathrm{mg} / \mathrm{kg}$, there will be a violation of the environmental information functions of the soil; $4.4-106 \mathrm{mg} / \mathrm{kg}$, the chemical, physicochemical, biochemical, and integral, along with the information, functions will be violated; and more than $106 \mathrm{mg} / \mathrm{kg}$, the physical functions of the soil will also be disrupted. It is obvious that the violation of chemical, physicochemical, biochemical, and most importantly integral functions of the soil, which ensure soil fertility, cannot be allowed. The silver concentration of $4.4 \mathrm{mg} / \mathrm{kg}$ should be considered the maximum permissible concentration (MPC) of silver in ordinary chernozem, or regional MPC (rMPC).

Thus, the rMPC of silver in ordinary chernozems is $4.4 \mathrm{mg} / \mathrm{kg}$ of silver in the soil, in sierosands $0.9 \mathrm{mg} / \mathrm{kg}$, and in brown forest soils $0.8 \mathrm{mg} / \mathrm{kg}$.

Established rMPC can be used in many environmental activities, such as environmental impact assessment (EIA), monitoring of soils and ecosystems, choice of methods of reclamation of silver-contaminated soils, risk assessment of man-made disasters, environmental expertise, and certification.

The rMPC developed can be used not only for soils of the South of Russia but also for similar soils in other regions of the world.

The most effective methods of soil rehabilitation in the south of Russia in the case of their pollution with silver in a certain concentration are presented in Table 3. The higher the concentration of silver in the soil, the more "radical" the method of rehabilitation should be. For example, if the silver content in ordinary chernozem is less than $0.5 \mathrm{mg} / \mathrm{kg}$ and there is no violation of environmental functions, then soil 
sanitation is not required in this case. If the silver concentration is $1.5-4.4 \mathrm{mg} / \mathrm{kg}$, then phytoremediation and washing are sufficient to reduce its concentration to $0.5 \mathrm{mg} /$ $\mathrm{kg}$ or less. If the silver concentration reaches $4.4-106 \mathrm{mg} / \mathrm{kg}$, then the introduction of organic substances, ion exchange resins, phosphorus fertilizers, lime, zeolites, etc. is required. If the silver content exceeds $106 \mathrm{mg} / \mathrm{kg}$, it is necessary to remove the contaminated soil layer and replace it with a new environmentally friendly and agricultural soil.

\section{Conclusions}

Silver pollution of the south of Russia soils in most cases leads to deterioration of their biological properties: the total number of bacteria, the abundance of bacteria of the genus Azotobacter, the activity of enzymes (catalase and dehydrogenases), and the phytotoxicity indicators decrease. The degree of reduction in biological properties depends on the silver concentration in the soil and the period from the contamination moment. In most cases, there is a direct relationship between the silver concentration and the degree of deterioration of the studied soil properties. The silver toxic effect was most pronounced on the 30th day after contamination.

When comparing the resistance of soils in the south of Russia to silver contamination, the following sequence was obtained: ordinary chernozem $>$ sierosands $\geq$ brown forest soil. The light granulometric composition of sierosands and the acidic reaction of the environment of brown forest soils, as well as the low content of organic matter, contribute to high mobility and, consequently, high ecotoxicity of silver in these soils.

The biological indicators used in this study have a high correlation coefficient with silver soil contamination and high sensitivity to silver soil pollution. It is advisable to use these biological indicators to monitor, diagnose, indicate, and normalize silver soil pollution.

The regional maximum permissible concentration (rMPC) of silver in ordinary chernozem (Haplic Chernozems, Loamic) is $4.4 \mathrm{mg} / \mathrm{kg}$, in sierosands (Haplic Arenosols, Eutric) $0.9 \mathrm{mg} / \mathrm{kg}$, and in brown forest soils (Haplic Cambisols, Eutric) $0.8 \mathrm{mg} / \mathrm{kg}$.

\section{Data Availability}

Primary data are presented in tables that accompany the text of the article. This dataset is the result of field and laboratory studies. It has not previously been published and can be used to verify the conclusions presented in this paper.

\section{Conflicts of Interest}

The authors declare that there are no conflicts of interest regarding the publication of this article.

\section{Acknowledgments}

This research was financially supported by the Ministry of Science and Higher Education of the Russian Federation within the framework of the state task in the field of scientific activity (Southern Federal University, no. 0852-2020-0029) and the President of the Russian Federation (NSh2511.2020.11).

\section{References}

[1] N. S. Kasimov and D. V. Vlasov, "Technophility of chemical elements at the beginning of the 21st century," Series 5: Geography, vol. 1, pp. 15-22, Vestnik of Moscow University, Moscow, Russia, 2012.

[2] J. O. Nriagu and J. M. Pacyna, "Quantitative assessment of worldwide contamination of air, water and soils by trace metals," Nature, vol. 333, no. 6169, pp. 134-139, 1988.

[3] B. Nordberg and B. Fowler, "Silver," in Handbook on the Toxicology of Metals. Volume II: Specific Metals, L. Friberg, G. Nordberg, and V. Vouk, Eds., pp. 521-530, Elsevier, New York, NY, USA, 1986.

[4] L. Ya. Kizilstein and S. V. Levchenko, "Trace elements and environmental concerns of coal power plants," Thermal Engineering, vol. 12, pp. 14-19, 2003.

[5] G. Xing, J. Zhu, and Z. Xiong, "Ag, Ta, Ru, and Ir enrichment in surface soil: evidence for land pollution of heavy metal from atmospheric deposition," Global Biogeochem Cycles, vol. 18, no. 1, pp. 1-5, 2004.

[6] D. A. Krylov, The Negative Impact of Trace Elements Contained in Coal, in Ash and Slag Dumps and Fly Ash of Coal Thermal Power Station, on the Environment and Human Health, Preprint of the Research Center of the Kurchatov Institute, Moscow, Russia, 2012.

[7] O. O. Medvedskaya, The Study of the Complex Impact of Metallurgical Enterprises on the Ecological State of the Novokuznetsk City, Notes of the Mining Institute, Novokuznetsk, Russia, 2009.

[8] M. A. Pashkevich and A. V. Alekseenko, "Monitoring of soil pollution in the area of influence of OJSC novoroscement," Mining Information and Analytical Bulletin (Scientific and Technical Journal), vol. 10, pp. 369-375, 2015.

[9] E. V. Sherbakova, "Ecological condition of soils and technogenic soils of the landfill of the city of Sloviansk-onKuban," Ecological Problems of Industrial Cities: Collection of Scientific Papers (The Saratov City), pp. 106-107, 2013.

[10] R. Eisler, "Strong dangers to fish, wildlife and invertebrates," Synoptic Survey, Biological Report 32, US Department of the Interior, National Biological Service, Washington, DC, USA, 1996.

[11] D. Stampoulis, S. K. Sinha, and J. C. White, "Assay-Dependent phytotoxicity of nanoparticles to plants," Environmental Science \& Technology, vol. 43, no. 24, pp. 9473-9479, 2009.

[12] C. Michels, S. Perazzoli, and H. M. Soares, "Inhibition of an enriched culture of ammonia oxidizing bacteria by two different nanoparticles: silver and magnetite," Science of the Total Environment, vol. 586, pp. 995-1002, 2017.

[13] S. Aueviriyavit, D. Phummiratch, and R. Maniratanachote, "Mechanistic study on the biological effects of silver and gold nanoparticles in Caco-2 cells-induction of the Nrf2/HO-1 pathway by high concentrations of silver nanoparticles," Toxicology Letters, vol. 224, no. 1, pp. 73-83, 2014.

[14] T. Benn, B. Cavanagh, K. Hristovski, J. D. Posner, and P. Westerhoff, "The release of nanosilver from consumer products used in the home," Journal of Environmental Quality, vol. 39, no. 6, pp. 1875-1882, 2010.

[15] S. Pal, Y. K. Tak, and J. M. Song, "Does the antibacterial activity of silver nanoparticles depend on the shape of the nanoparticle? A study of the gram-negative bacterium 
Escherichia coli," Applied and Environmental Microbiology, vol. 73, no. 6, pp. 1712-1720, 2007.

[16] W. M. A. Sillen, S. Thijs, G. R. Abbamondi et al., "Effects of silver nanoparticles on soil microorganisms and maize biomass are linked in the rhizosphere," Soil Biology and Biochemistry, vol. 91, pp. 14-22, 2015.

[17] M. Girilal, V. Krishnakumar, P. Poornima, A. Mohammed Fayaz, and P. T. Kalaichelvan, "A comparative study on biologically and chemically synthesized silver nanoparticles induced heat shock proteins on fresh water fish Oreochromis niloticus," Chemosphere, vol. 139, pp. 461-468, 2015.

[18] F. Eivazi, Z. Afrasiabi, and E. Jose, "Effects of silver nanoparticles on the activities of soil enzymes involved in carbon and nutrient cycling," Pedosphere, vol. 28, no. 2, pp. 209-214, 2018.

[19] S. K. Gogoi, P. Gopinath, A. Paul, A. Ramesh, S. S. Ghosh, and A. Chattopadhyay, "Green fluorescent protein-expressing Escherichia coli as a model system for investigating the antimicrobial activities of silver nanoparticles," Langmuir, vol. 22, no. 22, pp. 9322-9328, 2006.

[20] J. Beddow, B. Stolpe, P. Cole et al., "Effects of engineered silver nanoparticles on the growth and activity of ecologically important microbes," Environmental Microbiology Reports, vol. 6, no. 5, pp. 448-458, 2014.

[21] Z. Luo, Z. Chen, Z. Qiu et al., "Gold and silver nanoparticle effects on ammonia-oxidizing bacteria," Chemosphere, vol. 120, pp. 737-742, 2015.

[22] A. D. Samarajeewa, J. R. Velicogna, J. I. Princz, R. M. Subasinghe, R. P. Scroggins, and L. A. Beaudette, "Effect of silver nano-particles on soil microbial growth, activity and community diversity in a sandy loam soil," Environmental Pollution, vol. 220, pp. 504-513, 2017.

[23] H. Singh, J. Du, P. Singh, and T. H. Yi, "Extracellular synthesis of silver nanoparticles by Pseudomonas sp. THG-LS1.4 and their antimicrobial application," Journal of Pharmaceutical Analysis, vol. 8, no. 4, pp. 258-264, 2018.

[24] A. Tripathi, S. Liu, P. K. Singh et al., "Differential phytotoxic responses of silver nitrate $\left(\mathrm{AgNO}_{3}\right)$ and silver nanoparticle (AgNps) in Cucumis sativus L." Plant Gene, vol. 11, pp. 255-264, 2017.

[25] J. P. Fernandes, A. P. Mucha, T. Francisco, C. R. Gomes, and C. M. R. Almeida, "Silver nanoparticles uptake by salt marsh plants-implications for phytoremediation processes and effects in microbial community dynamics," Marine Pollution Bulletin, vol. 119, no. 1, pp. 176-183, 2017.

[26] R. M. Galazzi and M. A. Z. Arruda, "Evaluation of changes in the macro and micronutrients homeostasis of transgenic and non-transgenic soybean plants after cultivation with silver nanoparticles through ionomic approaches," Journal of Trace Elements in Medicine and Biology, vol. 48, pp. 181-187, 2018.

[27] Y.-F. Yang, Y.-H. Cheng, and C.-M. Liao, "Nematode-based biomarkers as critical risk indicators on assessing the impact of silver nanoparticles on soil ecosystems," Ecological Indicators, vol. 75, pp. 340-351, 2017.

[28] P. Das, S. Barua, S. Sarkar et al., "Mechanism of toxicity and transformation of silver nanoparticles: inclusive assessment in earthworm-microbe-soil-plant system," Geoderma, vol. 314, pp. 73-84, 2018.

[29] W. Liu, Z. Zeng, A. Chen et al., "Toxicity effects of silver nanoparticles on the freshwater bivalve Corbicula fluminea," Journal of Environmental Chemical Engineering, vol. 6, no. 4, pp. 4236-4244, 2018.

[30] A. E.-D. H. Sayed and H. A. M. Soliman, "Developmental toxicity and DNA damaging properties of silver nanoparticles in the catfish (Clarias gariepinus)," Mutation Research/Genetic Toxicology and Environmental Mutagenesis, vol. 822, pp. 34-40, 2017.

[31] N. B. Abramenko, T. B. Demidova, E. V. Abkhalimov, B. G. Ershov, E. Y. Krysanov, and L. M. Kustov, "Ecotoxicity of different-shaped silver nanoparticles: case of zebrafish embryos," Journal of Hazardous Materials, vol. 347, pp. 8994, 2018.

[32] S. M. Hussain, K. L. Hess, J. M. Gearhart, K. T. Geiss, and J. J. Schlager, "In vitro toxicity of nanoparticles in BRL 3A rat liver cells," Toxicology in Vitro, vol. 19, no. 7, pp. 975-983, 2005.

[33] C. Sun, N. Yin, R. Wen et al., "Silver nanoparticles induced neurotoxicity through oxidative stress in rat cerebral astrocytes is distinct from the effects of silver ions," NeuroToxicology, vol. 52, pp. 210-221, 2016.

[34] J. Jiravova, K. B. Tomankova, M. Harvanova et al., "The effect of silver nanoparticles and silver ions on mammalian and plant cells in vitro," Food and Chemical Toxicology, vol. 96, pp. 50-61, 2016.

[35] S. Gaillet and J.-M. Rouanet, "Silver nanoparticles: their potential toxic effects after oral exposure and underlying mechanisms-a review," Food and Chemical Toxicology, vol. 77, pp. 58-63, 2015.

[36] N. Hadrup, A. K. Sharma, and K. Loeschner, "Toxicity of silver ions, metallic silver, and silver nanoparticle materials after in vivo dermal and mucosal surface exposure: a review," Regulatory Toxicology and Pharmacology, vol. 98, pp. 257-267, 2018.

[37] K. S. Butler, D. J. Peeler, B. J. Casey, B. J. Dair, and R. K. Elespuru, "Silver nanoparticles: correlating nanoparticle size and cellular uptake with genotoxicity," Mutagenesis, vol. 30, no. 4, pp. 577-591, 2015.

[38] X. Guo, Y. Li, J. Yan et al., "Size- and coating-dependent cytotoxicity and genotoxicity of silver nanoparticles evaluated using in vitro standard assays," Nanotoxicology, vol. 10, no. 9, pp. 1373-1384, 2016.

[39] H. Cao and X. Liu, "Silver nanoparticles-modified films versus biomedical device-associated infections," Wiley Interdisciplinary Reviews: Nanomedicine and Nanobiotechnology, vol. 2, no. 6, pp. 670-684, 2010.

[40] B. Reidy, A. Haase, A. Luch, K. Dawson, and I. Lynch, "Mechanisms of silver nanoparticle release, transformation and toxicity: a critical review of current knowledge and recommendations for future studies and applications," $M a$ terials, vol. 6, no. 6, pp. 2295-2350, 2013.

[41] M. Gomathi, P. V. Rajkumar, A. Prakasam, and K. Ravichandran, "Green synthesis of silver nanoparticles using Datura stramonium leaf extract and assessment of their antibacterial activity," Resource-Efficient Technologies, vol. 3, no. 3, pp. 280-284, 2017.

[42] V. K. Sharma, K. M. Siskova, R. Zboril, and J. L. GardeaTorresdey, "Organic-coated silver nanoparticles in biological and environmental conditions: fate, stability and toxicity," Advances in Colloid and Interface Science, vol. 204, pp. 15-34, 2014.

[43] IUSS Working Group WRB, "World reference base for soil resources 2014, International soil classification system for naming soils and creating legends for soil maps," World Soil Resources Reports No. 106, Food and Agriculture Organization, Rome, Italy, 2015.

[44] H. J. M. Bowen, Environmental Chemistry of the Elements, p. 333, Academic Press, New York, NY, USA, 1979. 
[45] K. C. Jones, B. E. Davies, and P. J. Peterson, "Silver in Welsh soils: physical and chemical distribution studies," Geoderma, vol. 37, no. 2, pp. 157-174, 1986.

[46] V. A. Alekseenko and A. V. Alekseenko, Chemical Elements in Geochemical Systems. Soil Clarks in Residential Landscapes: Monograph, p. 380, Publishing House of the Southern Federal University, Rostov-on-the-Don, Russia, 2013.

[47] A. Kabata-Pendias, Trace Elements in Soils and Plants, CRC Press, Boca Raton, FL, USA, 4th edition, 2010.

[48] I. G. Asylbaev and I. K. Khabirov, "The concentration of chemical elements in soils and rocks of the Republic of Bashkortostan," Bulletin of the Ulyanovsk State Agricultural Academy, vol. 2, pp. 11-16, 2013.

[49] A. V. Puzanov, S. V. Baboshkina, I. A. Alekseev, and A. V. Saltykov, "Features of the accumulation and distribution of heavy metals and arsenic in the garden-vegetable crop system at the construction site of the Vostochny cosmodrome (Zeya river basin the Amur region)," Agricultural Chemistry, vol. 2, pp. 86-96, 2015.

[50] Y. Derya and A. Sasmaz, "Phytoremediation of As, Ag, and Pb in contaminated soils using terrestrial plants grown on Gumuskoy mining area (Kutahya Turkey)," Journal of Geochemical Exploration, vol. 182, pp. 228-234, 2017.

[51] A. V. Druzhinin and E. V. Karelina, "The main types of industrial silver deposits," RUDN Vestnik: A Series of Engineering Studies, vol. 1, pp. 35-41, 2008.

[52] S. I. Kolesnikov, K. Sh. Kazeev, and Y. V. Akimenko, "Development of regional standards for pollutants in the soil using biological parameters," Environmental Monitoring and Assessment, vol. 191, p. 544, 2019.

[53] I. Smith and B. Carson, "Trace metals in the environment," Silver, vol. 2, Ann Arbor Science Publishers, Ann Arbor, MI, USA, 1977.

[54] J. Yasur and P. U. Rani, "Environmental effects of nanosilver: impact on castor seed germination, seedling growth, and plant physiology," Environmental Science and Pollution Research, vol. 20, no. 12, pp. 8636-8648, 2013.

[55] P. Cvjetko, A. Milošić, A.-M. Domijan et al., "Toxicity of silver ions and differently coated silver nanoparticles in Allium cepa roots," Ecotoxicology and Environmental Safety, vol. 137, pp. 18-28, 2017.

[56] S. I. Kolesnikov, K. S. Kazeev, and V. F. Val'kov, "Effects of heavy metal pollution on the ecological and biological characteristics of common chernozem," Russian Journal of Ecology, vol. 31, no. 3, pp. 174-181, 2000.

[57] S. I. Kolesnikov, M. V. Yaroslavtsev, N. A. Spivakova, and K. S. Kazeev, "Comparative assessment of the biological tolerance of chernozems in the south of Russia towards contamination with $\mathrm{Cr}, \mathrm{Cu}, \mathrm{Ni}$, and $\mathrm{Pb}$ in a model experiment," Eurasian Soil Science, vol. 46, no. 2, pp. 176-181, 2013.

[58] S. Rahmatpour, M. Shirvani, M. R. Mosaddeghi, F. Nourbakhsh, and M. Bazarganipour, "Dose-response effects of silver nanoparticles and silver nitrate on microbial and enzyme activities in calcareous soils," Geoderma, vol. 285, pp. 313-322, 2017.

[59] F. Iram, M. S. Iqbal, M. M. Athar, M. Z. Saeed, A. Yasmeen, and R. Ahmad, "Glucoxylan-mediated green synthesis of gold and silver nanoparticles and their phyto-toxicity study," Carbohydrate Polymers, vol. 104, no. 1, pp. 29-33, 2014.

[60] H. Salama, "Effects of silver nanoparticles in some crop plants, common bean (Phaseolus vulgaris L.) and corn (Zea mays L.)," Journal of Biotechnology, vol. 3, no. 10, pp. 190-197, 2012.

[61] K. A. Langdon, M. J. McLaughlin, J. K. Kirby, and G. Merrington, "The effect of soil properties on the toxicity of silver to the soil nitrification process," Environmental Toxicology and Chemistry, vol. 33, no. 5, pp. 1170-1178, 2014.

[62] S. I. Kolesnikov, K. S. Kazeev, and V. F. Valkov, "The effect of heavy metal contamination on the microbial system in chernozem," Eurasian Soil Science, vol. 4, pp. 459-465, 1999.

[63] S. I. Kolesnikov, A. A. Popovich, K. S. Kazeev, and V. F. Val'kov, "The influence of fluorine, boron, selenium, and arsenic pollution on the biological properties of ordinary chernozems," Eurasian Soil Science, vol. 41, no. 4, pp. 400404, 2008

[64] S. I. Kolesnikov, A. V. Evreinova, K. S. Kazeev, and V. F. Val'kov, "Changes in the ecological and biological properties of ordinary chernozems polluted by heavy metals of the second hazard class (Mo, Co, Cr, and Ni)," Eurasian Soil Science, vol. 42, no. 8, pp. 936-942, 2009.

[65] G. V. Dobrovolsky and E. D. Nikitin, Ecology of Soils. The Doctrine of the Ecological Functions of Soils, M.: Nauka, Russia, 2006.

[66] S. I. Kolesnikov, K. S. Kazeev, and V. F. Valkov, "Ecological functions of soils and the effect of contamination with heavy metals," Eurasian Soil Science, vol. 12, pp. 1335-1340, 2002. 